\title{
URINARY PROTEOMICS IN KIDNEY TRANSPLANTATION
}

\author{
Goce Spasovski ${ }^{1}$, Irena Rambabova-Bushljetik ${ }^{1}$, Lada Trajceska ${ }^{1}$, Saso Dohcev ${ }^{2}$, \\ Oliver Stankov ${ }^{2}$, Sotir Stavridis ${ }^{2}$, Skender Saidi², Koco Dimitrovski ${ }^{3}$, Zivko Popov ${ }^{4}$ \\ ${ }^{1}$ Department of Nephrology, Medical Faculty, University of Ss. Cyril and Methodius, Skopje, N. Macedonia \\ ${ }^{2}$ Department of Urology, Medical Faculty, University of Ss. Cyril and Methodius, Skopje, N. Macedonia \\ ${ }^{3}$ Institute for Transfusion Medicine, Skopje, N. Macedonia \\ ${ }^{4}$ Macedonian Academy of Sciences and Arts Skopje, N. Macedonia
}

Corresponding author: Prof. Goce Spasovski University Department of Nephrology, Medical Faculty, University of Skopje, R. N. Macedonia, Vodnjanska 17, 1000 Skopje; тel.: +389 (0)2 0702682 32; fax: +389 (0)2 31781 02; e-mail: spasovski.goce@gmail.com

\section{ABSTRACT}

Although kidney transplantation is the best treatment option for end stage kidney disease, it is still associated with long-term graft failure. One of the greater challenges for transplant professionals is the ability to identify grafts with a high risk of failure before initial decline of eGFR with irreversible graft changes. Transplantation medicine is facing an emerging need for novel disease end point-specific biomarkers, with practical application in preventive screening, early diagnostic, and improved prognostic and therapeutic utility. The aim of our review was to evaluate the clinical application of urinary proteomics in kidney transplant recipients at risk for any type of future graft failure.

Keywords: kidney transplantation, proteomics, chronic allograft nephropathy

\section{INTRODUCTION}

End-stage renal disease (ESRD) is an irreversible deterioration of renal function where continuing life without renal replacement therapy (RRT), including hemodialysis, peritoneal dialysis, or transplantation could not be possible. Kidney transplantation is widely accepted as an optimal, cost-effective treatment which improves the quality of life, and prolongs the survival of the patients. throughout reduced risk for developing cardiovascular complications, morbidity and mortality. [1]

Despite improvement in short-term outcomes, long-term graft survival rates remain suboptimal. The clinical biomarkers currently in use - serum creatinine and increased urine protein load, or proteinuria - cannot determine early causes of allograft dysfunction in a timely manner and only reflect non-specific and late organ injury. [2]

Interest in proteinuria as a marker for detection of kidney transplant dysfunction was initiated in the early beginnings of kidney transplantation. [3] A number of published studies reported urine total protein excretion correlated independently with the patient's death, allograft failure, and cardiovascular morbidity and mortality after transplantation. [4-6] 


\section{BIOPSY OR "LIQUID BIOPSY"}

Early detection of the causes of graft dysfunction and consequent graft loss is important. The current modality for definitive diagnosis of graft abnormalities is the graft biopsy. [7] Hence, kidney biopsy is considered the gold standard for the diagnosis of kidney diseases. Even though the procedure is safe, some risk of performing it on a sole transplanted kidney is always possible. The fear and discomfort of patients after kidney biopsy or eventual delay in the procedure performance could impact early diagnosis of the graft dysfunction and any related therapeutic strategy. $[8,9]$

Thus, modern medicine faces an urgent need for a new diagnostic tool, one that is non-invasive and provides screening, early diagnostics, and accurate therapeutic approaches. The new era of biomarkers may provide a better understanding not only of the pathological processes but also for normal biological function and approaches to modern follow up of pharmaceutical treatment. The definition of Biomarkers is provided by the Biomarkers Definition Working Group. [10] In kidney transplantation, the most appropriated sample besides those from a biopsy is urine. Urine provides adequate sources for biomarker discovery. The word "Proteomics" was used to obtain a quantitative description of protein expression and its changes under the influence of a biological process, disease or drug treatment. High-throughput methods were used for quantitative analysis. [11]

Proteomics can contribute to the clarification of proteome of different cell types, tissue or a specific parts of the tissue, and disclose proteome changes in biologic fluids (e. g. urinary or plasma proteome). Proteins and peptides within a specific body unit comprise a specific cell and tissue proteome, one that is also prone to changes over the time in response to various conditions. [12]

Urine represents a modified ultrafiltrate of plasma, with lower protein concentration at approximately 1000 -fold times more when compared to plasma. But urinary proteins and peptides are less complex and have a higher stability when compared with plasma proteins. [13] In healthy individuals, about $70 \%$ of the urinary proteome originates from the kidney and the urinary tract, whereas the remaining 30\% represent proteins filtered by the glomerulus. [14] The urinary proteome consists of extensive information about the kidney, and assessment of the urinary proteomics could be considered as 'liquid biopsy'. [15] Analyzing the urinary proteomes today is a commonly used tool in the field of research, as well as in the transition process in the implementation of clinical practice. The modern high throughput technologies offer assessment of thousands of peptides and proteins in the urine sample within a short time.

While traditional proteomic methods analyze at the rate of only one protein at a time, recent advances facilitate the comparison of the expression of multiple proteins simultaneously. [16] Disparity to proteinuria, smaller genomic peptides and protein chains ranging from 1000 20,000 Da present in urine are not detectable by using a standard biochemical test for urinary protein in clinical laboratories. The concentration of these urinary proteomes could be 1000 times lower, therefore requiring special techniques for detection. Proteomic investigators have numerous techniques to facilitate human proteome studies, including standard gels, such as one-dimensional gel electrophoresis and two-dimensional gel electrophoresis, as well as non-gel based methods using mass spectrometry [like matrix-assisted laser ionization (MALDI)]; liquid chromatography mass spectrometry (LC-MS); and surface-enhanced laser ionization with time-of-flight mass spectrometry (SELDI-TOF-MS). [17]

\section{PROTEOMIC ANALYSIS - A DIAG- NOSTIC TOOL IN KIDNEY TRANS- PLANTATION}

Proteomic urine analysis could predict the diagnosis of renal transplant early on and could impact graft function and survival in the long term. Urinary proteome in transplant recipients could differentiate stable graft function from acute tubulointerstitial rejection (AR), urinary tract infection (UTI), acute tubular necrosis (ATN), calcineurin inhibitor (CNI) toxicity, Chronic allograft dysfunction $(\mathrm{CAD})$ and transplant glomerulopathy (TG). [18]

Solid organ transplantation between nonHLA identical individuals provoke a stimulus for alloimmune responses. Over time, immunosuppressive drugs have become effective at inhibiting 
the transplant recipient's immune response. After the introduction of immunosuppression, acute rejection rates have declined from nearly $100 \%$ in the initial era of organ transplantation to approximately $10 \%$ currently, and there have been dramatic improvements in the 1-year graft survival rate. [19] Acute rejection has the potential to significantly affect graft survival, and it is a reason for unexplained graft dysfunction in transplant recipients. [20]

As our understanding of alloimmune response has evolved, the classification of clinical acute rejection episodes was established. Initially described as "steroid responsive" and "steroid non-responsive," as acute rejection is now broadly defined as either "T cell mediated" or "antibody mediated," respectively. The major immunologic risk factors for graft survival at the time of transplantation have been attributed to factors such as overall level of anti-HLA sensitization (panel reactive antibody - PRA), repeat transplant, black race, and recipient age. [21]

A study with 526 kidney transplant recipients evaluated traditional risk factors showing pre-transplant donor-specific antibodies (DSA) and HLA A/B/DR mismatch are the main predictors of antibody-mediated rejection and $\mathrm{T}$ cell-mediated rejection, respectively. [21 ]The PRA and repeated transplantation had no predictive effect. [22]

Still, the gold standard for diagnosis of acute rejection in kidney transplant recipients is the kidney biopsy. Allograft histology is interpreted using Banff classification for allograft pathology and over time has undergone extensive revision. While diagnostic criteria for $\mathrm{T}$ cell mediated rejection have been minimally changed, the classification for humoral rejection was firstly recognized in the early 2000's and continues to evolve. [23]

\section{PROTEOMICS IN ACUTE REJECTION}

At present, several urine biomarkers have been studied for detection of allograft injury, including CXCL9, CXCL10, CCL2, NGAL, IL-18, cystatin C, KIM-1 and Tim-3. [24] The recent results of the Clinical Trials in Organ Transplantation-01 (CTOT-01 trial). CTOT-01 was a multicenter observational study defining biomarkers in 280 adults and pediatric kidney transplant recipients. The aim of the study was to compare and val- idate urinary mRNAs and proteins as biomarkers in order to diagnose biopsy-proven acute rejection (AR) and to divide the patients into groups based on their risk for developing AR or allograft dysfunction. Among markers tested for diagnosing $\mathrm{AR}$, urinary CXCL9, mRNA, and CXCL9 protein were the most reliable ones. Low urinary CXCL9 protein 6 months posttransplant was observed in stable allograft recipients with stable allograft function between 6 and 24 months. Whereas if urinary CXCL9 was absent at 6 months posttransplant, this was defined as a subgroup at low risk for initial immune injury. [25]

The study by Sidgel et al. matched urine samples of 396 kidney transplant recipients with renal allograft biopsy. Centralized and blinded histology data from paired graft biopsies was used to classify urine samples into diagnostic categories of acute rejection (AR), chronic allograft nephropathy (CAN), BK virus nephritis, and stable graft. A total of 245 urine samples were analyzed and 35 proteins identified for their ability to divide the 3 major transplant injury clinical groups: a panel of 11 urinary peptides for AR (93\% AUC), 12 urinary peptides for CAN (99\% AUC), and 12 urinary peptides for BK virus nephritis $(83 \%$ AUC). [26]

Mertens et al. performed a multicenter case-control study to identify a urinary biomarker for antibody mediated rejection (AMR) in a training cohort $(\mathrm{n}=249)$ and an independent, prospective multicenter cohort study for validation $(n=391)$. Concomitant biopsies to classify the samples according to the Banff classification were used. The primary endpoint of the study was the diagnostic accuracy of the urinary biomarker for AMR in the validation cohort. The study identified a set of 10 urinary proteins which accurately discriminated patients with $(n=60)$ and without $(n=189)$ AMR in the training cohort with an area under the curve (AUC) of 0.98 (95\% CI, 0.96-1.00). The negative predictive value of the 10-protein marker set for exclusion of AMR was 0.99, and the positive predictive value was 0.33. [27]

\section{URINARY PROTEOMICS IN CHRONIC ALLOGRAFT NE- PHROPATHY (DYSFUNCTION)}

Despite improvements in immunosuppressive therapy in solid organ transplantation, long- 
term allograft survival remains as low as 50\%. CAN is the major cause of late graft loss. The generic term CAN was described in Banff's 2007 classification in favor of 'interstitial fibrosis and tubular atrophy without evidence of any specific etiology'. [28]

The process is progressive and time-dependent. The early phase of tubulointerstitial damage occurs soon after transplantation as a result of ischemia-reperfusion injury, acute tubular necrosis and acute rejection. Subsequently, cellular infiltration and alloimmune injury with microvascular and glomerular abnormalities immune-mediated fibrointimal vascular hyperplasia, transplant glomerulopathy and capillary injury and calcineurin toxicity provoke a pathologic mechanism and lead to progressive damage of the transplanted kidney. Once the causes and exact mechanisms of injury are elucidated, targeted strategies to prevent the progression and chronic damage may become available. [29]

Among the general population, progressive CKD is generally perceived in later stages by a continuous decline in glomerular filtration and the presence of albuminuria or proteinuria. A classifier based on 273 urinary peptides, termed as CKD273 is well suited for the early detection of CKD and for prognosis of progression. [30, 31] PRIORITY, a multicentric intervention study, including diabetic patients without CKD, used CKD273 to identify those individuals who show molecular signs of diabetic nephropathy, based on the positive scoring of the CKD273 classifier. In a group of individuals with type 2 diabetes and normoalbuminuria, a high-risk score from the urinary proteomic classifier CKD273 was associated with an increased risk of progression to microalbuminuria over a median of $2 \cdot 5$ years, independent of clinical characteristics. [32]

Recently, 52 living donor kidney recipients with a long term follow up were urine sampled at month 24 after transplantation and analyzed for the patient's peptide profiles with the CKD273 classifier which showed a significant positive correlation with serum creatinine at every time point with a maximum at month $48(\mathrm{r}=0.51$, $\mathrm{p}=0.0002$ ). A moderate inverse correlation was observed for the percentage of annual change (slope) in the glomerular filtration rate $(\mathrm{r}=-0.29$, $\mathrm{p}=0.05)$. Using the composite endpoint graft loss and death within the next six years from proteomic analysis as a classification criterion, receiver operating characteristics (ROC) anal- ysis revealed an area under the curve value for CKD273 of 0.89 which was superior to that of 0.67 for the Nankivell eGFR calculation. Hence, the stratification of patients by CKD273 revealed a hazard ratio of 16.5 with a $95 \%$ CI from 2.5 to 109.9 for the prevalence of graft loss in case of CKD273 positivity [33].

Hussein et al. performed study with 75 participants divided into three groups: Group 1: 25 patients with CAN, Group 2: 25 stable allograft function and a third group of 25 healthy control subjects, matched for age and sex. Urine samples were collected and analyzed using MALDI-TOF MS. Five peaks represented the proteomic profile that differentiates between the CAN patients and the control group with a sensitivity rate of $100 \%$ and a specificity rate of $100 \%$, and the five peaks also differentiate between the transplant patients with normal renal functions and the control groups with a sensitivity rate of $96.8 \%$ and a specificity rate of $95.5 \%$. [34]

O'Riordan presented a study of urinary proteome from 75 renal transplant recipients and 20 healthy volunteers. The study analyzed via surface-enhanced laser desorption and ionization (SELDI) MS. Several urinary proteins associated with advanced CAN were identified including $\alpha 1$-microglobulin, $\beta 2$-microglobulin, prealbumin, and endorepellin, the antiangiogenic C-terminal fragment of perlecan. [35]

The study performed by Cassidy et al. included 34 renal transplant patients with histologically proven CAN and 36 renal transplant patients with normal renal function. The study described the novel biomarker pattern with the potential to separate renal transplant recipients with CAN from those with normal renal function. The study also confirmed the importance of $\beta 2$ microglobulin as a biomarker. Significantly higher urinary concentrations of neutrophil gelatinase-associated lipocalin, clusterin, and kidney injury biomarker 1 were found in patients with CAN compared to those with normal kidney function. [36]

Tetaz et al. performed a study to evaluate predictive values of urinary proteomics for CAN. Twenty-nine urinary samples were collected over three months, post-transplant, and analyzed by SELDI-TOF technology. CAN was confirmed by allograft biopsy at One year after transplantation with increased level of serum creatinine. Here, 18 biomarkers were predictive of CAN occurrence. The biomarker with the high- 
est diagnostic performance was a protein of 8860 Da with a sensitivity rate of $93 \%$ and a specificity rate of $65 \%$. The combination of these biomarkers in two multivariate analyses improved the diagnostic potential of CAN. Significance of these biomarkers and a decisional algorithm constituted of 3 proteins was confirmed among an independent cohort of patients with undetermined CAN status one-year post-transplant. [37]

\section{URINARY PROTEOMICS IN CALCINEURIN TOXICITY (CNIT)}

The calcineurin inhibitors (CNI) play an important role in organ transplantation, including Cyclosporin (CsA) and tacrolimus (TAC) in the current clinical use. Both drugs differ in their molecular structure and intracellular binding characteristics, but have immunosuppressive properties which inhibit a calcium- and calmodulin-dependent phosphatase protein or calcineurin. CsA binds to cyclophilin, while TAC binds to FKBP12 (originally designated FK506) and functions as a more potent immunosuppressant. CNI nephrotoxicity in long term use in kidney transplant recipients has been described and associated with a lack of improvement in kidney allograft survival over the years. Nephrotoxicity has been described as 'universal', even in grafts with excellent function. Acute CsA nephrotoxicity is a reversible process which reduces or ceases CsA therapy. But chronic CsA nephrotoxicity presents itself clinically as glomerulosclerosis, tubulointerstitial fibrosis and tubular atrophy. [38] Early detection of the potential nephrotoxicity and changes in immunosuppressive protocols give rise to the importance of finding non-invasive biomarkers that can be attributed to longterm graft survival.

In the study by Carreras-Planella, urine had been collected from kidney transplant patients who were treated with CNI and the patients were then divided into 3 groups (one group of patients who had normal kidney function; one group with CNIT, and one which presented interstitial fibrosis and tubular atrophy). The urinary biomarker - urinary extracellular vesicles $(\mathrm{uEV})$ - were developed and the proteome was analyzed to gain insight into the changes associated with CNIT. Members of the uroplakin and plakin families were described and significantly upregulated in the CNIT group. This single pilot study presented the potential of $\mathrm{uEV}$ as a source of non-invasive protein biomarkers for detection and monitoring of renal alteration associated with CNIT. [39]

Neutrophil gelatinase-associated lipocalin (NGAL) and kidney injury molecule 1 (KIM1) are noninvasive urinary biomarkers that are believed to be highly sensitive to CNI-induced AKI. [40, 41] Both biomarkers are synthesized in the proximal and distal tubules, and may be well associated with renal vasoconstriction and the interstitial fibrosis caused by CNI-induced nephrotoxicity. Results from a clinical study showed that NGAL staining contributed to the classification of renal damage after kidney transplantation and could predict the development of AKI approximately 2 days before a rise in serum creatinine. [42]

NGAL plays an important role in the early prediction of acute tubular necrosis in the general population and this is clinically expressed via a high mortality rate, especially in patients requiring renal replacement therapy (RRT). Early, post-transplantation, acute kidney injury can result from acute tubular necrosis (ATN) followed by a delayed graft function (DGF), acute rejection (AR) or drug toxicity (e. g. calcineurin inhibitor) as the leading causes of AKI. [43]

The identification of biomarkers NGAL and IL-18 in the urine of kidney transplant recipients have been predictive for delayed graft function. IL-18 is more specific to ischemic AKI, separately from nephrotoxicity, CKD or urinary tract infections. The published data may suggest the novel biomarkers NGAL, IL-18, and KIM-1 are considered urinary biomarkers of AKI. [44] On the other hand, NGAL is an extracellular 25$\mathrm{kDa}$ ligand-binding protein, as well as the earliest induced protein in a kidney suffering from ischemic or nephrotoxic damage. With its small molecular size and stable structure resistant to degradation, NGAL can be excreted and detected in urine in the very early stages of kidney injury. The concentration is significantly higher in patients with tubulitis or other tubular pathologies, and it could also be associated with subclinical tubulitis in the early months following kidney transplantation. [45]

Urine biomarker analysis using SELDI-TOF-MS in renal transplant recipients with ATN showed also small proteins such as NGAL, KIM-1, and sodium-transporter-at-apical-mem- 
brane (NaHE-3). Tubular biomarkers like adenosine-deaminase and carbonic-anhydrase-enzyme, retinol-binding-protein and alpha-1-microglobulin were also included in this group of proteomes. [46]

\section{URINARY PROTEOMICS IN TRANSPLANT GLOMERULOPATHY (TG)}

Transplant glomerulopathy (TG) is a major cause of chronic graft dysfunction that does not have an effective therapy. It is defined as a unique pathologic condition limited to kidney allografts. Histopathological examination considered duplication of the basement membranes in the absence of an immune complex mediated glomerulonephritis and thrombotic microangiopathy. [47]

Although the histological definition of TG is well characterized, the pathophysiological pathways leading to TG development are still poorly understood. Patients with a TG as a histological diagnosis, may have nephrotic range proteinuria and/or hypertension and/or kidney graft function deterioration at clinical presentation. The development of TG is associated with poor kidney graft outcomes. A number of associated factors for the development of TG include age, presence of antibodies directed towards HLA molecules especially class II donor specific antibodies (DSA), hepatitis $\mathrm{C}$ positive serology (HCV), and acute rejection beyond 3 months post-Tx. De novo DSA presence has been identified in younger recipients and associated to noncompliance to immunosuppressive therapy, and may result in chronic antibody mediated, humoral injury with the development of TG. [48]

In order to improve long term allograft survival there is a need for noninvasive biomarkers for $\mathrm{cABMR}$ that might facilitate screening and earlier diagnosis. In a case-controlled study, urine samples of 24 pediatric renal transplant recipients with cABMR have been matched with 36 pediatric patients without cABMR. Proteomics have been analyzed using capillary electrophoresis and mass spectrometry (CE-MS). The authors found the proteomic classifier established and validated in this study as a useful diagnostic tool which can identify children with cABMR after kidney transplantation in order to detect candidates for early graft biopsy, thereby avoiding unnecessary biopsies. In addition, new biomarkers were supposed to contribute to the intensification of immunosuppressive treatment should the findings be confirmed as with DSA positive patients. [49]

Another study identified potential proteomic biomarkers for chronic active antibody-mediated rejection (CAMR) in kidney transplant recipients. Among 385 KTRs enrolled in a multicenter study, 26 kidney transplant recipients had biopsy-proven CAMR, 57 with long-term graft survival (LGS), and 10 rejection-free matched KTRs. A proteomic approach was employed to measure urinary extracellular vesicle (uEV) changes in KTRs. The authors identified and validated six proteomic biomarkers to distinguish CAMR from LGS and clarified one CAMR-specific proteomic biomarker to distinguish rejection-free KTRs. Nevertheless, further clinical studies are warranted before the novel urinary proteomic biomarkers can be applied in clinical use for early diagnosis and monitoring of the clinical response to the treatment of CAMR. [50]

\section{URINARY PROTEOMICS IN BK VIRUS NEPHROPATHY}

The virulence and significance of the BK virus (BKV) in healthy individuals is not well understood, but in immunocompromised patients, including solid organ allograft recipients and bone marrow transplant patients, it has been recognized as a major pathogenic virus leading to allograft loss. Most adults become seropositive at four years of age, and a majority of them develop antibodies. Hence, at initiation of the immunosuppressive therapy, immediately after renal transplantation, the latent polyomavirus can be reactivated in the kidney, causing lytic damage of renal tubular epithelial cells, further resulting in an inflammatory interstitial nephropathy, associated with functional impairment due to tubular fibrosis and atrophy. [51] A considerable number of kidney transplant recipients experience clinically significant BKV associated nephropathy (BKVAN). According to the published data, viruria have been reported in $30-60 \%$, viremia in $10-30 \%$, and BKVAN in up to $10 \%$. In absence of a BKV specific antiviral 
therapy, the transplant clinicians reduce immunosuppressive drugs. [52]

Early detection of patients with increased risk of BKVAN is important in improving kidney allograft outcome. Current guidelines recommend regular observation for BKV reactivation through the detection of infected urothelial cells in urine (decoy cells) or viral nucleic acid in urine or blood. These methods do not have any sensitivity for early detection, and non-invasive techniques for this purpose are yet deficient. Urinary proteomics is a promising tool in BKV nephropathy differentiation and treatment.

The discovery-phase biomarker development study has examined the possibility of developing a noninvasive method to differentiate BKVAN from AR. Using Surface-enhanced laser desorption/ionization (SELDI) time-of-flight mass spectrometry analysis, the authors compared urine samples of 21 patients with BKVAN, 28 patients with AR (Banff Ia to IIb), and 29 patients with stable graft function. SELDI analysis confirmed proteomic profiles that were significantly different in the BKVAN group versus the AR and stable transplant groups. It was concluded that urinary proteomic analysis may propose a noninvasive method that can distinguish BKVAN from AR in clinical practice. The identification of an individual proteomic profile can improve the clinical screening method. [53]

Another study reported a mass spectrometry (MS)-based method for the detection of BKV derived proteins isolated from urine samples. Peptides detected by MS derived from Viral Protein 1 (VP1) allowed differentiation between different subtypes. The association has been observed between higher decoy cell numbers and the presence of the VP1 subtype Ib-2. The results of the analysis supported the hypothesis that certain viral subtypes may be associated with more severe BKVAN. [54]

Further clinical studies for urinary proteomics which include a higher number of patients are warranted to confirm the initial published data and to develop noninvasive methods for BKVAN diagnostics.

\section{CONCLUSION}

Implementation of proteomics analysis in the field of kidney transplantation opens new ap- proaches for prognosis and early accurate diagnostics in order to reduce risk factors for allograft failure such as acute rejection, calcineurin toxicity, and chronic allograft nephropathy. The main advantage of urine as a source of biomarkers for detection of allograft dysfunction, is that it is a fluid readily available as a non-invasive sample, and it provides sustainable information. The future clinical application of urinary biomarkers is expected not only to improve early diagnosis but also to replace some invasive diagnostics, especially in kidney diseases with a single functioning kidney.

Unfortunately, none of the identified biomarkers have made their transition into the routine clinical practice, and contemporary medicine is still waiting for the practical application of the ideal biomarker. Current analysis suggests that instead of one single biomarker, a combination of proteomic classifiers could better reflect different biological and pathophysiological process in the field of organ transplantation, and it holds great promise and potential for highly enhanced diagnosis and care of transplant patients in the future.

\section{REFERENCES}

1. Abecassis M, Bartlett ST, Collins AJ, et al. Kidney transplantation as primary therapy for endstage renal disease: a National Kidney Foundation/Kidney Disease Outcomes Quality Initiative (NKF/KDOQITM) conference. Clinical journal of the American Society of Nephrology: CJASN. 2008; 3: 471-480.

2. Coemans M, Süsal C, Döhler B, Anglicheau D, Giral M, Bestard O, Legendre C, Emonds MP, Kuypers D, Molenberghs G, Verbeke G, Naesens M (2018). Analyses of the short- and longterm graft survival after kidney transplantation in Europe between 1986 and 2015. Kidney Int. 94: 964-973.

3. Bertram L. Kasiske. Proteinuria and Other Urinary Biomarkers in Kidney Transplantation: Why Are We Still Waiting for Godot?2011 Am.J Kidney Dis2011; 57 (5): 654-656.

4. Roodnat J.I.Mulder P.G. Rischen-Vos J.et al. Proteinuria after renal transplantation affects not only graft survival but also patient survival. Transplantation. 2001; 72: 438-444.

5. Jean-Michel Halimi Inass Laouad Matthias Buchler Azmi Al-Najjar Valérie Chatelet Tarik Sqa1li Houssaini Hubert Nivet Yvon Lebranchu. Ear- 
ly Low-Grade Proteinuria: Causes, Short-Term Evolution and Long-Term Consequences in Renal Transplantation. Am J Transplant. 2005; 5: 2281-2288.

6. Paul A. Devine, Aisling E. Courtney \& Alexander P. Maxwell Cardiovascular risk in renal transplant recipients. Journal of Nephrology 2019; 32, 389-399.

7. Robert B. Colvin, The renal allograft biopsy, Kidney International.1996;50 (3):1069-1082.

8. Lees JS, McQuarrie EP, Mordi N, Geddes CC, Fox JG, Mackinnon B. Risk factors for bleeding complications after nephrologist-performed native renal biopsy. Clin Kidney J. 2017; (10)4: 573-577.

9. TrajceskaL, Severova-Andreevska G, Dzekova-Vidimliski P, Nikolov I, Selim G, Spasovski G, Rambabova-Busletik I, Ristovska V, Grcevska L, Sikole A.Complications and Risks of Percutaneous Renal Biopsy. Open Access Maced J Med Sci. 2019; 7(6): 992-995.

10. Biomarkers Definitions Working Group.Biomarkers and surrogate endpoints: preferred definitions and conceptual framework. Clin Pharmacol Ther. 2001; 69(3): 89-95.

11. Anderson, N.L.; Anderson, N.G. Proteome and proteomics: New technologies, new concepts, and new words. Electrophoresis 1998, 19, 1853-1861.

12. Fliser D, Novak J, Thongboonkerd V, Argilés A, Jankowski V, Girolami MA, Jankowski J, Mischak $\mathrm{H}$. Advances in urinary proteome analysis and biomarker discovery. J Am Soc Nephrol. 2007; 18(4): 1057-1071.

13. Hortin GL, Sviridov D. Diagnostic potential for urinary proteomics. Pharmacogenomics. 2007; 8: $237-255$

14. Thongboonkerd V, Malasit P. Renal and urinary proteomics: current applications and challenges. Proteomics 2005; 5: 1033-1042.

15. Mischak H. Pro: Urine proteomics as a liquid kidney biopsy: no more kidney punctures! Nephrol Dial Transplant (2015) 30: 532-537.

16. Cassidy H, Slyne J, Frain H, Slattery C, Ryan MP, McMorrow T. High-Throughput Proteomic Approaches to the Elucidation of Potential Biomarkers of Chronic Allograft Injury (CAI). Proteomes. 2013; 1(2): 159-179.

17. Monteoliva, L.; Albar, J.P. Differential proteomics: An overview of gel and non-gel based approaches. Brief. Funct. Genomic Proteomic 2004;3(3): 220-239.

18. Quintana LF, Solé-Gonzalez A, Kalko SG, et al. Urine proteomics to detect biomarkers for chronic allograft dysfunction. J Am Soc Nephrol. 2009; 20(2): 428-435. doi:10.1681/ASN.2007101137.

19. Zand MS. Immunosuppression and immune monitoring after renal transplantation. Semin Dial. 2005; 18(6): 511-519.
20. Pallardó Mateu LM, Sancho Calabuig A, Capdevila Plaza L, Franco Esteve A. Acute rejection and late renal transplant failure: risk factors and prognosis. Nephrol Dial Transplant. 2004; Suppl 3:iii38-42.

21. Santos AH Jr, Casey MJ, Womer KL. Analysis of Risk Factors for Kidney Retransplant Outcomes Associated with Common Induction Regimens: A Study of over Twelve-Thousand Cases in the United States. J Transplant. 2017; 2017: 8132672.

22. Wehmeier C, Hönger $\mathrm{G}$, Cun $\mathrm{H}$, Amico $\mathrm{P}$, Hirt-Minkowski P, Georgalis A, Hopfer H, Dickenmann M, Steiger J, Schaub S. Donor Specificity but Not Broadness of Sensitization Is Associated With Antibody-Mediated Rejection and Graft Loss in Renal Allograft Recipients. Am J Transplant. 2017; 17(8): 2092-2102.

23. Jeong HJ. Diagnosis of renal transplant rejection: Banff classification and beyond. Kidney Res Clin Pract. 2020; 39(1): 17-31

24. Kim SC, Page EK, Knechtle SJ. Urine proteomics in kidney transplantation. Transplant Rev (Orlando). 2014; 28(1): 15-20.

25. Hricik DE, Nickerson P, Formica RN, et al. Multicenter validation of urinary CXCL9 as a risk-stratifying biomarker for kidney transplant injury. Am J Transplant. 2013; 13(10): 26342644.

26. Sigdel TK, Gao Y, He J, et al. Mining the human urine proteome for monitoring renal transplant injury. Kidney Int. 2016; 89(6): 1244-1252.

27. Mertens I, Willems H, Van Loon E, et al. Urinary Protein Biomarker Panel for the Diagnosis of Antibody-Mediated Rejection in Kidney Transplant Recipients. Kidney Int Rep. 2020; 5(9): 1448-1458.

28. Li C, Yang CW. The pathogenesis and treatment of chronic allograft nephropathy. Nat Rev Nephrol. 2009; 5(9): 513-519.

29. Brian J. Nankivell, in Kidney Transplantation (Sixth Edition), 2008

30. Argilés Á, Siwy J, Duranton F, Gayrard N, Dakna M, Lundin U, Osaba L, Delles C, Mourad G, Weinberger KM, Mischak H. CKD273, a new proteomics classifier assessing CKD and its prognosis. PLoS One. 2013 May 14; 8(5): e62837.

31. Schanstra JP, Zürbig P, Alkhalaf A, Argiles A, Bakker SJ, Beige J, Bilo HJ, Chatzikyrkou C, Dakna M, Dawson J, Delles C, Haller H, Haubitz M, Husi H, Jankowski J, Jerums G, Kleefstra N, Kuznetsova T, Maahs DM, Menne J, Mullen W, Ortiz A, Persson F, Rossing P, Ruggenenti P, Rychlik I, Serra AL, Siwy J, Snell-Bergeon J, Spasovski G, Staessen JA, Vlahou A, Mischak H, Vanholder R. Diagnosis and Prediction of CKD Progression by Assessment of Urinary Peptides. J Am Soc Nephrol. 2015; 26(8): 1999-2010. 
32. Tofte N, Lindhardt M, Adamova K, Bakker SJL, Beige J, Beulens JWJ, et al. PRIORITY investigators. Early detection of diabetic kidney disease by urinary proteomics and subsequent intervention with spironolactone to delay progression (PRIORITY): a prospective observational study and embedded randomised placebo-controlled trial. Lancet Diabetes Endocrinol. 2020; 8(4): 301-312.

33. Rambabova-Bushljetik I, Metzger J, Siwy J, Dohcev S, Bushljetikj O, Filipce V, Trajceska L, Mischak H, Spasovski G. Association of the chronic kidney disease urinary proteomic predictor CKD273 with clinical risk factors of graft failure in kidney allograft recipients.Nephrol Dial Transplant. 2021 Oct 11:gfab297. doi: 10.1093/ ndt/gfab297. Online ahead of print.

34. Amr K. Hussien, Pacint E. Moez, Hala S. Elwakil \& Hayam A. Elagaan (2020) Identification of urinary proteomic profile of patients with chronic allograft nephropathy, Alexandria Journal of Medicine, 56:1, 93-104.

35. O'Riordan E, Orlova TN, Mendelev N, Patschan D, Kemp R, Chander PN, Hu R, Hao G, Gross SS, Iozzo RV, Delaney V, Goligorsky MS. Urinary proteomic analysis of chronic allograft nephropathy. Proteomics Clin Appl. 2008 Jul; 2(7-8): 1025-35.

36. Cassidy H, Slyne J, O'Kelly P, Traynor C, Conlon PJ, Johnston O, Slattery C, Ryan MP, McMorrow T. Urinary biomarkers of chronic allograft nephropathy. Proteomics Clin Appl. 2015; 9(5-6): 574-85.

37. Tetaz R, Trocmé C, Roustit M, Pinel N, Bayle F, Toussaint B, Zaoui P. Predictive diagnostic of chronic allograft dysfunction using urinary proteomics analysis. Ann Transplant. 2012; 17(3): $52-60$.

38. Issa N, Kukla A, Ibrahim H, N: Calcineurin Inhibitor Nephrotoxicity: A Review and Perspective of the Evidence. Am J Nephrol 2013; 37: 602-612.

39. Carreras-Planella L, Juega J, Taco O, et al. Proteomic Characterization of Urinary Extracellular Vesicles from Kidney-Transplanted Patients Treated with Calcineurin Inhibitors. Int J Mol Sci. 2020; 21(20): 7569.

40. Gustafsson F, Gude E, Sigurdardottir V, Aukrust P, Solbu D, Goetze JP, et al. Plasma NGAL and glomerular filtration rate in cardiac transplant recipients treated with standard or reduced calcineurin inhibitor levels. Biomark Med. 2014; 8: 239-245.

41. Yadav B, Prasad N, Agrawal V, Jaiswal A, Rai $M$, Sharma R, et al. Urinary Kidney injury molecule-1 can predict delayed graft function in living donor renal allograft recipients. Nephrology. 2015; 20: 801-806.
42. Mishra J, Ma Q, Kelly C, Mitsnefes M, Mori K, Barasch J, et al. Kidney NGAL is a novel early marker of acute injury following transplantation. Pediatr Nephrol. 2006; 21: 856-863.

43. Mannon RB. Acute Kidney Injury in Kidney Transplants: New Insights. Nephron. 2019; 143(3): 193-196.

44. Parikh CR, Jani A, Mishra J, Ma Q, Kelly C, Barasch J, Edelstein CL, Devarajan P. Urine NGAL and IL-18 are predictive biomarkers for delayed graft function following kidney transplantation. Am J Transplant. 20061; 6(7): 1639-1645.

45. Schaub S, Mayr M, Hönger G, Bestland J, Steiger J, Regeniter A, Mihatsch MJ, Wilkins JA, Rush D, Nickerson P: Detection of subclinical tubular injury after renal transplantation: comparison of urine protein analysis with allograft histopathology. Transplantation 2007; 84: 104-112.

46. Suhail SM. Significance of urinary proteome pattern in renal allograft recipients. J Transplant. 2014; 2014:139361.

47. Mohamed N, Avila-Casado C. Transplant Glomerulopathy: Pathogenesis, Morphology, and Prognosis. J Transplant Technol Res. 2011, S: 1.

48. 47. Hanf W, Bonder CS, Coates PT. Transplant glomerulopathy: the interaction of HLA antibodies and endothelium. J Immunol Res. 2014; 2014: 549315.

49. Kanzelmeyer NK, Zürbig P, Mischak H, Metzger J, Fichtner A, Ruszai KH, Seemann T, Hansen M, Wygoda S, Krupka K, Tönshoff B, Melk A, Pape L. Urinary proteomics to diagnose chronic active antibody-mediated rejection in pediatric kidney transplantation - a pilot study. Transpl Int. 2019; 32(1): 28-37.

50. Jung HY, Lee CH, Choi JY, et al. Potential urinary extracellular vesicle protein biomarkers of chronic active antibody-mediated rejection in kidney transplant recipients. Journal of chromatography. B, Analytical Technologies in the Biomedical and Life Sciences. 2020; 1138: 121958.

51. Funahashi Y. BK Virus-Associated Nephropathy after Renal Transplantation. Pathogens. 2021; 10(2): 150.

52. Hirsch HH, Knowles W, Dickenmann M, Passweg J, Klimkait T, Mihatsch MJ, et al. Prospective study of polyomavirus type BK replication and nephropathy in renal-transplant recipients. $\mathrm{N}$ Engl J Med. 2002; 347(7): 488-496.

53. Jahnukainen T, Malehorn D, Sun M, Lyons-Weiler J, Bigbee W, Gupta G, et al. Proteomic analysis of urine in kidney transplant patients with BK virus nephropathy. J Am Soc Nephrol. 2006; 17(11): 3248-3256.

54. Konietzny R, Fischer R, Ternette N, et al. Detection of $\mathrm{BK}$ virus in urine from renal transplant subjects by mass spectrometry. Clin Proteomics. 2012; 9(1): 4 . 


\section{Резиме}

\section{УРИНАРНИ ПРОТЕОМИЦИ ВО БУБРЕЖНАТА ТРАНСПЛАНТАЦИЈА}

\section{Гоце Спасовски ${ }^{1}$, Ирена Рамбабова-Бушлетик ${ }^{1}$, Лада Трајческа ${ }^{1}$, Сашо Дохчев $^{2}$, Оливер Станков ${ }^{2}$, Сотир Ставридис ${ }^{2}$, Скендер Саиди ${ }^{2}$, Кочо Димитровски ${ }^{3}$, Живко Попов ${ }^{4}$}

${ }^{1}$ Катедра за нефрологија, Медицински факултет, Универзитет Св. Кирил и Методиј, Скопје, РС Македонија

${ }^{2}$ Катедра за урологија, Медицински факултет, Универзитет Св. Кирил и Методиј, Скопје, РС Македонија

${ }^{3}$ Институт за трансфузиона медицина, Скопје, РС Македонија

${ }^{4}$ Македонска академија на науките и уметностите Скопје, РС Македонија

Иако трансплантацијата на бубрезите е најдобрата опција за третман на бубрежната болест во краен стадиум, таа, сепак, е поврзана со долгорочно откажување на графтот. Еден од поголемите предизвици за професионалците во трансплантацијата е способноста да се идентификуваат графтовите со висок ризик од неуспех пред првичното опаѓање на eGFR со неповратни промени на графтот. Трансплантациската медицина се соочува со потреба за нови биомаркери специфични за крајниот стадиум на болеста, со практична примена во превентивниот скрининг, раната дијагностика и подобрената прогностичка и терапевтска корист. Целта на нашиот труд беше да се процени клиничката примена на уринарните протеомици кај примателите на трансплантиран бубрег, кои се изложени на ризик за секаков вид иден неуспех на графтот.

Клучни зборови: трансплантација на бубрег, протеомика, хронична нефропатија на алографт 